\title{
A comparison of different methods of estimating sire transmitting ability of some milk traits in a herd of Holstein Friesian cattle
}

\begin{abstract}
Summary
A total of 1931 normal first lactation records of Holstein Friesian cows kept at Dena Farm in Egypt during the period from 1987 to 1994 were used to estimate phenotypic and genetic parameters for 90 day milk yield ( 90 $\mathrm{dMY}$ ), 305 day milk yield ( $305 \mathrm{dMY}$ ) and lactation period (LP). In addition, 76 bulls with at least ten daughters were used to compare three methods of sire transmitting ability.

A least squares analysis of variance show significant effect of month and year of calving and age at first calving for different traits studied, except the effect of age at first calving on LP.

Heritability estimates for $90 \mathrm{dMY}, 305 \mathrm{dMY}$ and LP were $0.39 \pm 0.08,0.27 \pm 0.07$ and $0.14 \pm 0.05$, respectively. Genetic and phenotypic correlations between different traits were positive and significant.

Sires with at least ten daughters were evaluated by best linear unbiased prediction (BLUP), least squares means (LSM) and regression of the future daughters mean on the present daughters mean. The product moment correlations between different traits studied were positive and high $(=0.96)$.
\end{abstract}

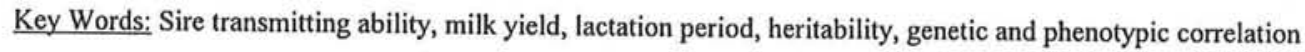

\section{Zusammenfassung}

Titel der Arbeit: Vergleich verschiedener Methoden der Schătzung von Bullenzuchtwerten anhand einiger Milchleistungsmerkmale in einer ägyptischen Holstein Friesian Herde

Anhand von 1931 Erstlaktationen bei Holstein Friesian Kuhen eines Betriebes in den Jahren 1987 bis 1994 wurden phänotypische und genetische Parameter für folgende Merkmale geschätzt: 90-Tage-Milchleistung, 305Tage-Milchleistung und Laktationsperiode. Für den Vergleich der drei Schătzmethoden BLUP, LSM und REG standen 76 Bullen mit mindestens 10 Tochtern zur Verfugung. Die Varianzanalyse zeigte bei den einzelnen Merkmalen signifikante Effekte bei Kalbemonat und -jahr sowie Erstkalbealter, mit Ausnahme des Einflusses vom Erstkalbealter auf die Laktationsperiode. Die Heritabilitătsschătzwerte betrugen fur die Merkmale: 90 Tage-Milchleistung $0,39 \pm 0,08,305$-Tage-Milchleistung $0,27 \pm 0,07$, Laktationsperiode $0,14 \pm 0,05$. Die genetischen und phănotypischen Korrelationen zwischen den betrachteten Merkmalen waren signifikant positiv. Die Ergebnisse des Vergleiches der Schätzmethoden werden diskutiert.

Schlüsselwörter: Bullenzuchtwerte, Milchleistung, Laktationsperiode, Heritabilităt, genetische und phänotypische Korrelationen

\section{Resumen}

Titulo del Articulo: Una comparación de métodos diferentes de estimación de transmión del padre capacidad para leche rasgos en un rebaño de holstein frisón

Un total de 1931 primeras lactaciones registradas normales de Holstein frisonas vacas que criaron al Dena Granga en Egipto durante los períodos de 1987 a 1994 se usaron a estimar parámetros fenotipos y genéticos por 90 día leche rendimiento, 305 día leche rendimiento y períodos del lactacion. Además, 76 toros con por lo menos 10 hijas se usaron a comparar tres métodos de transmión del padre capacidad.

Análisis de cuadrados minimos de variación muestra significativa el efecto del mes y el año del parto y la edad al primero parto para rasgos diferentes estudio, excepto el efecto de edad al primero parto sobre lactacion períodos. 
Heritabilidad estima para 90 dia leche rendimiento, 305 dia leche rendimiento y períodos del lactacion eran 0.39 $\pm 0.08,0.27 \pm 0.07$ y $0.14 \pm 0.05$ respectivamente.

Correlaciones genéticos y fenotipos entre rasgos diferentes eran positivas y significativas.

Padres con por lo menos 10 hijas fueron evaluadas por predicción mejor lineal imparcial, medias de los cuadrados minimos y regresión de media de las hijas futuras en media de las hijas presentes. Las correlaciones del producto entre rasgos diferentes estudiado era positiva y alta $(=0.96)$.

Palabras claves: Capacida de transmision del padre, periodos del lactacion, correlacion genéticos y fenotipos

\section{Introduction}

Milk production can not be measured on males, thus sire genetic evaluation must be based either on records of female ancestors or on records of the progeny (progeny test). Evaluation on the basis of progeny test results has much greater accuracy than pedigree evaluation (VAN VLECK, 1979).

There are many different methods of sire breeding value has been estimated by different workers in different countries. EL-CHAIFE (1981), ABUBAKAR et al. (1986), VIJ and TIWANA (1988), ABDEL GLIL (1991, 1996), REGE (1991), KHATTAB (1992), KHATTAB and MOURAD (1992), METRY et al. (1994) and TRIVENI et al. (1996) used the best linear unbiased prediction (BLUP). FAHMY (1972), VIJ and TIWANA (1988) and KHATTAB (1992) used average of daughters or least squares means for sire effect. KHATTAB et al. (1987), VIJ and TIWANA (1988) estimated sire breeding values by the regression of the future daughters mean on the present daughters mean.

The objective of this study were: (1) to estimate genetic and phenotypic parameters for first milk traits; for example 90 day milk yield ( $90 \mathrm{dMY}), 305$ day milk yield ( 305 $\mathrm{dMY}$ ) and lactation period (LP) and (2) to compare three methods of estimating sire transmitting ability for Holstein Friesian cattle in Egypt.

\section{Data}

\section{Material and Methods}

A total of 1931 first lactation milk records of Holstein Friesian cows maintained at Dena Farm in Egypt during the period 1987 to 1994 were used. The number of sires and average of daughters per sire were 76 and 24.79, respectively. Sires with less than ten daughters were excluded. Artificial insemination using frozen semen was used. Traits studied were first 90 day milk yield, 305 day milk yield and lactation period. More information of the data, feeding system and management of that herd were described by ATIL and KHATTAB (1998).

\section{Estimating of genetic parameters}

Data were analysed using Mixed Model Least Squares and Maximum Likelihood Computer Program of HARVEY (1987). The mixed model used for the analysis included the fixed effects of year and month of calving as a fixed effects, age at first calving (AFC) as a regression and sire as a random effect on each of $90 \mathrm{dMY}, 305$ $\mathrm{dMY}$ and LP. Estimates of sire and residual components of variances and covariances 
were computed according to II of HENDERSON (1953). Estimates of heritability $\left(\mathrm{h}^{2}\right)$, genetic correlations $\left(r_{g}\right)$ with standard errors $(\mathrm{SE})$ and phenotypic correlation $\left(\mathrm{r}_{\mathrm{p}}\right)$ were estimated according to HARVEY (1987).

\section{Estimating of sire transmitting ability (ETA's)}

ABUBAKAR et al. (1986) suggested that ten daughters per sire are considered a minimum number for the evaluation of sires using BLUP procedures in Tropical areas. KHATTAB et al. (1987) using another set of Friesian cattle in Egypt, reported that the accuracy of sire evaluation increases as the number of daughters per sire increased. They also suggested that it is necessary to estimate the sire evaluation based on a large number of daughters per sire. Therefore, transmitting ability of sires at least ten daughters will be examined.

Three methods of sire transmitting abilities were followed:

\section{1- Best Linear Unbiased Prediction (BLUP)}

The above model can be written in matrix notation as:

$$
Y=X f+Z s+W b+e
$$

where $Y$ was a vector of observations for each trait, $X$ was a known fixed design matrix, $f$ was an unknown vector of fixed effects representing the mean, year and month of calving, $Z$ was a known design matrix, $s$ was an unobservable vector of random sire effect, $W$ was a vector of covariate variable (independent variable), $b$ was a vector of partial regression of $Y$ on $W$ and e was unobservable random vector of errors with mean zero and variance - covariance matrix $I \sigma^{2} e$.

The mixed model equations (HENDERSON, 1953) are

$$
\left[\begin{array}{lll}
X^{\prime} X & X^{\prime} Z & X^{\prime} W \\
Z^{\prime} X & Z^{\prime} Z+G & Z^{\prime} W \\
W^{\prime} X & W^{\prime} Z & W^{\prime} W
\end{array}\right] *\left[\begin{array}{l}
f \\
s \\
b
\end{array}\right]=\left[\begin{array}{l}
X^{\prime} Y \\
Z^{\prime} Y \\
W^{\prime} Y
\end{array}\right]
$$

where $G=\left(4-\mathrm{h}^{2}\right) / \mathrm{h}^{2}$ for each trait was added to the diagonal of sire effects in the matrix.

\section{2- Least Squares Means (LSM):}

Constants of each bull were obtained by using a model including sire, year and month of calving as a fixed effects and age at first calving as a regression.

3- Regression Of The Future Daughters Mean On The Present Daughters Mean (REG):

$$
R E G=b(D-\bar{X})
$$

where $b=\mathrm{n} /(\mathrm{n}+\mathrm{k}), \mathrm{n}$ is the number of half sib daughters, $\mathrm{k}$ is equal $\left(\left(4-\mathrm{h}^{2}\right) / \mathrm{h}^{2}\right), D$ is the traits adjusted to year and month of calving as a fixed and age at first calving as a regression and $\bar{X}$ is the least squares mean of the herd.

Product moment correlations for the three methods of sire transmitting ability for each bull were computed. 


\section{Results and Discussion}

Least squares means of $90 \mathrm{dMY}, 305 \mathrm{dMY}$ and LP are $1911 \pm 63 \mathrm{~kg} ., 5139 \pm 164 \mathrm{~kg}$. and $281 \pm 7 \mathrm{~d}$, respectively. The present means of $90 \mathrm{dMY}$ and were higher than those reported by HUSSEIN (1996) using another set Holstein Friesian cattle in Egypt, being $1748 \mathrm{~kg}$ and $4938 \mathrm{~kg}$, respectively. Also, the present mean of LP was lower than that reported by KHATTAB and SULTAN (1991) (341 d). The differences between the present estimates and those reported by other workers could be due to different climatic and management. Herds could be possibly the genetically different on be caused by different models used.

Least squares analysis of variances for $90 \mathrm{dMY}, 305 \mathrm{dMY}$ and LP are presented in Table 1. Significant $(\mathrm{P}<0.01)$ effects of month and year of calving on each of the traits studied were found. These results are agree with the findings were also reported on Friesian raised in other countries by MILAGRES et al. (1989). REGE (1991), KAYA (1996), MAKUZA and McDANIEL (1996) and KELM et al. (1997). Differences in milk yield and lactation period attributed to month and year of calving were interpreted to be due to climatic, nutritional and managerial conditions which changed from one year or month of calving to another.

Table 1

F ratios for factors affecting 90 day milk yield ( $90 \mathrm{dMY}$ ), 305 day milk yield ( $305 \mathrm{dMY}$ ) and lactation period (LP) (Varianzanalyse, geschătzte Effekte und Produktionsmerkmale unterschiedlicher Kontrollabschnitte)

\begin{tabular}{|c|c|c|c|c|}
\hline Source of Variation & d.f. & $\begin{array}{c}90 \mathrm{dMY} \\
\mathrm{F}\end{array}$ & $\begin{array}{c}305 \mathrm{dMY} \\
\mathrm{F}\end{array}$ & $\begin{array}{l}\text { LP } \\
\text { F }\end{array}$ \\
\hline Sire & 75 & $3.64^{* *}$ & $2.82^{* * *}$ & $1.91^{* *}$ \\
\hline Month of calving & 11 & $4.61^{* * *}$ & 0.91 & $2.66^{* *}$ \\
\hline $\begin{array}{l}\text { Year of calving } \\
\text { Regressions }\end{array}$ & 7 & $37.03^{* * *}$ & $37.93^{* *}$ & $15.22^{* *}$ \\
\hline AFC, linear & 1 & $11.26 * *$ & $5.62^{* *}$ & 1.46 \\
\hline AFC, quadratic & 1 & $94.65 * *$ & $27.72^{* *}$ & 2.27 \\
\hline $\begin{array}{l}\text { Remainder mean squares } \\
\text { Number of records }=1931\end{array}$ & 1835 & 153919 & 1374676 & 4201 \\
\hline
\end{tabular}

Estimates of partial linear and quadratic regression coefficients of $90 \mathrm{dMY}$ and 305 $\mathrm{dMY}$ an age at first calving were significant $(\mathrm{P}<0.01)$, being $4.03 \pm 1.20 \mathrm{~kg} / \mathrm{mo}$ and $0.34 \pm 0.036 \mathrm{~kg} / \mathrm{mo}^{2}$, respectively for $90 \mathrm{dMY}$ and $8.49 \pm 3.58 \mathrm{~kg} / \mathrm{mo}$ and $0.56 \pm 0.11$ $\mathrm{kg} / \mathrm{mo}^{2}$, respectively for $305 \mathrm{dMY}$. The curvilinear relationships of milk yield on age at first calving were reported by SALLAM et al. (1990), KHATTAB and SULTAN (1991), MANSOUR (1992) and KHATTAB et al.(1994). The present results suggested that reduction in age at first calving is desirable to prolong the length of herd life and to economic the cost of rearing the heifers.

The partial linear and quadratic regression coefficients of LP on age at first calving were not significant. SALLAM et al. (1990) and KHATTAB and SULTAN (1991) found similar results.

The present results indicate the importance of considering the effect of year and season of calving and age at first calving in the model used for describing productive traits for unbiased sire evaluation. 
Results obtained in the present study show that the sire of the heifers had a highly significant effect on $90 \mathrm{dMY}, 305 \mathrm{dMY}$ and LP $(\mathrm{P}<0.01$, Table 1), accounting for $9.62,6.85$ and $3.54 \%$, of the total variance for $90 \mathrm{dMY}, 305 \mathrm{dMY}$ and LP, respectively. This is similar to results of BASU et al. (1982), ABUBAKAR et al. (1986), MILAGNES et al. (1989), ABDEL GLIL (1991 and 1996) and KHATTAB and SULTAN (1991), which ranged from $1.6 \%$ and $10 \%$.

Heritability estimates $\left(h^{2}\right)$, genetic correlations $\left(r_{g}\right)$ and phenotypic correlations $\left(r_{p}\right)$ between different traits studied are presented in Table 2. Estimates of $h^{2}$ for $90 \mathrm{dMY}$ and $305 \mathrm{dMY}$ were $0.39 \pm 0.08$ and $0.27 \pm 0.07$ (Table 2). The present means and moderate and similar to those estimates reported RAGAB et al. (1973), BASU et al. (1982), KHATTAB and SULTAN (1991), ABDEL GLIL (1996) and KAYGISIZ and VANLI (1997) which ranged from 0.26 to 0.48 . The present results concluded that the genetic improvement in milk production traits could be achieved trough selective breeding values.

Heritability estimate for LP was $0.14 \pm 0.05$ (Table 2). This estimate is in agreement with those reported by RAGAB et al. (1973) (0.21) and KHATTAB and SULTAN (1991) (0.18).

Genetic and phenotypic correlations between $90 \mathrm{dMY}$ and $305 \mathrm{dMY}$ were $0.56 \pm 0.12$ and 0.51 , respectively (Table 2). The present results indicate that $90 \mathrm{dMY}$ can be a good indicators for production in $305 \mathrm{dMY}$. These results are in agreement with other estimates found by (RAGAB et al., 1973; KHATTAB and SULTAN, 1991; ABDEL GLIL, 1991 and 1996; and KAYA, 1996).

Table 2

Estimates of heritability (on diagonal), genetic (below diagonal) and phenotypic (above diagonal) correlations for productive traits (Heritabilitatsschatzwerte, genetische (oberhalb Diagonale) und phänotypische Korrelationen furr die Produktionsmerkmale)

\begin{tabular}{cccc}
\hline Traits correlated & $90 \mathrm{dMY}$ & $305 \mathrm{dMY}$ & LP \\
\hline $90 \mathrm{dMY}$ & $0.39 \pm 0.08$ & 0.51 & 0.11 \\
$305 \mathrm{dMY}$ & $0.56 \pm 0.12$ & $0.27 \pm 0.07$ & 0.52 \\
LP & $0.92 \pm 0.13$ & $0.54 \pm 0.15$ & $0.14 \pm 0.05$ \\
\hline
\end{tabular}

Genetic and phenotypic correlation between LP and each of $90 \mathrm{dMY}$ and $305 \mathrm{dMY}$ were positive and significant $(\mathrm{P}<0.01$, Table 2$)$. The present results indicate that there was a positive phenotypic association between milk and lactation period.

Sire values for $90 \mathrm{dMY}, 305 \mathrm{dMY}$ and LP were estimated by using the procedure of best linear unbiased prediction (BLUP), least squares means (LSM) and the regression of the future daughters mean on the present daughters mean (REG). Number of daughters per sire ranged from 10 to 77 .

Estimates of sire transmitting abilities as deviations from the mean for $90 \mathrm{dMY}$ ranged from -205 to $245 \mathrm{~kg}$ for BLUP values, from -374 to 543 for LSM values and from 227 to $280 \mathrm{~kg}$ for REG values. With the range being 450,917 and $507 \mathrm{~kg}$, respectively. Similarly, EL-CHAIFE (1981) working on Friesian X Native cows in Egypt, found that the range of breeding values of 17 sires for 100-day milk yield ranged from -56 to $88 \mathrm{~kg}$. KHATTAB and MOURAD (1992) working on Egyptian buffaloes found that the estimation of sire transmitting ability for $90 \mathrm{dMY}$ ranged from -24 to $37 \mathrm{~kg}$. 
Estimates of sire transmitting abilities for $305 \mathrm{dMY}$ ranged from -506 to $675 \mathrm{~kg}$ for BLUP values, from -964 to $895 \mathrm{~kg}$ for LSM values and from -531 to 492 for REG values, with the range being 1181,1859 and $1023 \mathrm{~kg}$, respectively. Similarly, ABUBAKAR et al. (1986) with 15512 lactation records of daughters of 138 sires (each with ten or more daughters) found that predicted sire values (BLUP) in 305 dMY ranged from -400 to $400 \mathrm{~kg}$. ABDEL GLIL (1991) with 1653 lactation records for daughters of 163 sires (each with 5 or more daughters) found that predicted sire values (BLUP) ranged from -466 to $681 \mathrm{~kg}$. Also, ZARNECKI et al. (1990) found that the expected breeding values for $305 \mathrm{dMY}$ ranged from -481 to $571 \mathrm{~kg}$. In Egyptian buffaloes, KHATTAB and MOURAD (1992) found that the estimation of sire transmitting ability for $305 \mathrm{dMY}$ ranged from $147 \mathrm{~kg}$ to $154 \mathrm{~kg}$. Also, METRY et al. (1994) working on 316 buffaloes cows sired by 77 sires, found that expected breeding values for $305 \mathrm{dMY}$ ranged from -424 to $247 \mathrm{~kg}$. They suggested that potential genetic improvement of milk yield by mass selection was estimated at $2.2 \%$ per year.

The present estimates showed large genetic differences between sires for $90 \mathrm{dMY}$ and $305 \mathrm{dMY}$, which indicate the high potential for rapid genetic improvement in milk production of Friesian cattle raised in Egypt through selection.

Estimates of sire transmitting ability for LP ranged from -16 to $19 \mathrm{~d}$ for BLUP values, -59 to $51 \mathrm{~d}$ for LSM values and from -18 to $21 \mathrm{~d}$ for REG, with the range being 35 , 110 and 39 d, respectively. EL-CHAIFE (1981) working Friesian X Native cows in Egypt, found that sire values for LP ranged from -36 to $46 \mathrm{~d}$. Also, KHATTAB (1992) working on Friesian cattle in Egypt found that the sire values for LP ranged from -29 to $29 \mathrm{~d}$.

The similarity of ranges of BLUP and REG values show the suitability of these two methods for estimating sire transmitting ability for the three traits studied.

The product moment correlations between estimates of sire transmitting abilities for different traits (Table 3 ) were positive and high (0.96).

KHATTAB (1992) arrived at the same conclusion by using another herd of Friesian cattle.

The product moment correlations between BLUP and LSM estimates were higher than the estimates of 0.71 and 0.88 reported by GLIL and PARMAR (1988) and VIJ and TIWANA (1988) working on Red Dane X Sahiwal and Murrah buffaloes, respectively.

Table 3

Product moment correlations between estimates of different methods of estimating sire transmitting abilities for productive traits (Beziehungen zwischen den unterschiedlichen Schătzmethoden bei den Produktionsmerkmalen)

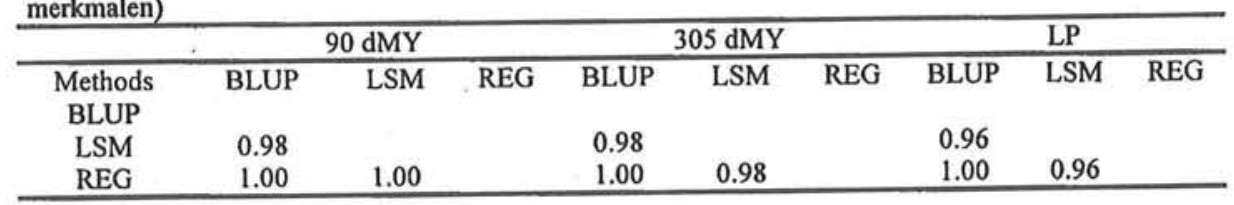

The high product moment correlations of ETA's between 90 dMY and 305 dMY for the three methods indicated that sire evaluation could be possible using initial milk yield in order to decrease the time required for progeny test. This will reduce the cost of evaluation, and decrease the generation interval to increase the annual genetic gain. 
Also, the high product moment correlations between different methods for different traits, indicated that the three methods were reported to succeed for estimating sire transmitting ability.

\section{References}

ABUBAKAR, B.Y; McDOWELL, R.E; WELLINGTON, K.E.; VAN VLECK, L.D.: Estimating genetic values for milk production in the tropics. J. Dairy Sci. 69 (1986), 1087 - 1092 ABDEL GLIL, M.F.:

Sire differences for milk production traits in Friesian cattle. Ph.D. Thesis Faculty of Agric. Zarazig Univ. Egypt, 1991

ABDEL GLIL, M.F.:

Estimation of genetic parameters and trend of some milk traits in a herd of Friesian cows in Egypt. Egypt J. Anim. Prod. (in Press), (1996).

ATIL, H. ; KHATTAB, A.S.:

Seasonal age correction factors for 305 day milk yield in Holstein cattle. Pakistan J. Biological Sci. 2 (1999), $296-300$

BASU, S.B.; BAHTRAGAR, D.S.; TANEJA, A.:

Estimates of genetic parameters for lactation performance in Tharparker cattle. Indian J. Anim. Sci., 45 (1982), $279-283$

EL-CHAIFE, O.M.:

Studies on cattle (cows and buffoloes) sire evaluation and genetic parameters of partial lactation, dry period and service period. M.Sc. Thesis Faculty of Agric. Alex. Univ., Egypt, 1981

FAHMY, S.K.:

The reliability of using 5 daughters in esimating the breeding values of dairy sires. Agric. Research Review., 50 (1972), 13 - 17

GLIL, G.S.; PARMAR, O.S.:

Genetic merits of Red Dane bulls used in a crossbreeding project. Indian J. Anim. Sci., 58 (1988), 811 813

HARVEY, W.R.:

User's guide for LSMLMW. Mixed model least squares and maximum likelihood computer program. The Ohio State Univ., USA, (1987)

HENDERSON, C.R.:

Estimation of variance and covariance components. Biometrics 9 (1953), 226 - 252

HUSSENN, A.M.:

Age correction factors for some productive traits in a herd of Holstein Friesian cattle. M.Sc. Thesis. Fac.

KAYA, I.: of Agric. Tanta Univ., Egypt, (1996)

Parameter estimates for persistency of lactation and relationship of persistency with milk yield in Holstein cattle. Ph.D. Thesis, Ege Univ. Izmir, Turkey, 1996

KAYGISIZ, A.; VANLI, Y:

Genetic analysis of the Brown cattle herd of Van Agricultural Vacational High School. Tarim Bilimleri Dergisi, 2 (1997), 111 - 115

KELM, S.C.; FREEMAN, A.E.; KELLEY, D.H.:

Realized versus expected gains in milk and fat production of Holstein cattle, considering effects of days open. J. Dairy Sci. 80 (1997), 1786 - 1794

KHATTAB, A.S.; MABROUK, M.M.S.; EL-HAKIM, A.M.:

Lactation records adjusted for days open in sire evaluation. J. Agric. Res., Tanta Univ., 13 (1987), 286 297

KHATTAB, A.S.; SULTAN, Z.A.:

A comparison of different selection indices for genetic improvement of some dairy traits in Friesian cattle in Egypt. J. Anim. Breed. Genet. 108 (1991), 349 - 354

KHATTAB, A.S.:

A comparison between different methods of estimating sire transmitting ability of some milk traits in Friesian cows in Egypt. J. Agric. Res. Tanta Univ. 18 (1992), 569 - 576 
KHATTAB, A.S.; MOURAD, K.A.:

Estimation of genetic parameters and genetic trends for some milk traits in a herd of Egyptian buffaloes. Egypt. J. Anim. Prod. 29 (1992), 33 - 44

KHATTAB, A.S.; ABDEL GLIL, M.F.; SALEM, A.Y.:

Estimation of genetic parameters and sire values for lifetime production and longevity traits in Friesian cows in Egypt. J. Agric. Sci. Mansoura Univ. 2 (1994), 483 - 498

MAKUZA, S.M.; McDANIEL, T.C.:

Effects of days dry, previous days open and current days open on milk yield of cows in Zimabwe and North Carolina. J. Dairy Sci. 79 (1996), $702-709$

MANSOUR, H.:

Some reproductive performance parameters of Holstein cattle in The Kingdom Saudi Arabia. Annals Agric. Sci., 37 (1992), 85 - 94

METRY, G.H.; WILK, J.C.; McDOWELL, R.E.; EL-RIGALATY, H.A.:

Factors affecting the performance of Egyptian buffoloes. Annals of Agric. Sci., Moshtohor, Egypt. 32 (1994), 827 - 841

MILAGRES, J.C.,A.; ALVES, A.J.R.; PEREIRA, J.C.; TEIXEIRA, N.M.:

Effect of genetic and environmental factors on milk yield of crossbreed Holstein, Brown Swiss, Jersey and Zebu cows. (A.B.A:, 57:4786), (1989)

RAGAB, M.T.; ABDEL AZIZ, A.S.; MOURAD, H.M.:

Phenotypic and genetic parameters of some productive traits in a herd of Friesian cattle at Tahreer

REGE, J.E.O.: province. Egypt. J. Anim. Prod. 1 (1973), 3 - 8

Genetic analysis of reproductive and productive performance of Friesian cattle in Kenya. J. Anim. Breed. Genet. 108 (1991), 412 - 423

SALLAM, M.T.; EL-FEEL, F.M.; KHATTAB, A.S.:

Effect of genetic and nongenetic factors on productive and reproductive traits in Friesian cows in Egypt. El-Minia. J. Agric. Res. 12 (1990), 521 - 539

TRIVENI, D.; RAHAJE, K.L.; TNEJA, V.K.; DUTT, T.:

Estimations of sire breeding values and genetic and phenotypic trends for various economic traits in VAN VLECK, D.: Murrah buffaloes. Indian. J. of Anim. Sci. 66 (1996), 1145 - 1148

Notes on theory and application of selection principles for the genetic improvement of animals. Department of Animal Sci., Cornell Univ., Ithaca, New York 14853, (1979)

VIJ, R.K.; TIWANA, M.S.:

A note on evaluation of buffaloes sires. Indian J. Dairy Sci. 41 (1988), 500 - 503

ZARNECKI, A.; NORMAN, H.D.; JAMNOZIK, J.:

Lifetime performance of ten Friesian strains in Poland. $4^{\text {th }}$ World Congress on Genetic Applied Livestock Production. Edinburgh, 23-27 July, (1990)

Received: 1998-10-23

Accepted: $2000-02-23$

\author{
Authors' addresses \\ Dr. HÜLYA ATIL \\ Ege University, Faculty of Agriculture, Animal Sciences Dept., \\ Bornova, Izmir \\ Turkey \\ Prof. Dr. ADEL SALAH KHATTAB \\ Tanta University, Faculty of Agriculture, Animal Production Dept., \\ Tanta \\ Egypt
}

